\title{
Intramyocellular lipids and insulin sensitivity: does size really matter?
}

Citation for published version (APA):

Hesselink, M. K., Mensink, M., \& Schrauwen, P. (2004). Intramyocellular lipids and insulin sensitivity: does size really matter? Obesity Research, 12(5), 741-2. https://doi.org/10.1038/oby.2004.88

Document status and date:

Published: 01/01/2004

DOI:

10.1038/oby.2004.88

Document Version:

Publisher's PDF, also known as Version of record

Document license:

Taverne

Please check the document version of this publication:

- A submitted manuscript is the version of the article upon submission and before peer-review. There can be important differences between the submitted version and the official published version of record.

People interested in the research are advised to contact the author for the final version of the publication, or visit the DOI to the publisher's website.

- The final author version and the galley proof are versions of the publication after peer review.

- The final published version features the final layout of the paper including the volume, issue and page numbers.

Link to publication

\footnotetext{
General rights rights.

- You may freely distribute the URL identifying the publication in the public portal. please follow below link for the End User Agreement:

www.umlib.nl/taverne-license

Take down policy

If you believe that this document breaches copyright please contact us at:

repository@maastrichtuniversity.nl

providing details and we will investigate your claim.
}

Copyright and moral rights for the publications made accessible in the public portal are retained by the authors and/or other copyright owners and it is a condition of accessing publications that users recognise and abide by the legal requirements associated with these

- Users may download and print one copy of any publication from the public portal for the purpose of private study or research.

- You may not further distribute the material or use it for any profit-making activity or commercial gain

If the publication is distributed under the terms of Article $25 \mathrm{fa}$ of the Dutch Copyright Act, indicated by the "Taverne" license above, 


\title{
Intramyocellular Lipids and Insulin Sensitivity: Does Size Really Matter?
}

\author{
Matthijs K.C. Hesselink, * Marco Mensink, $\dagger$ and Patrick Schrauwen $\dagger$
}

Storage of free fatty acids as triacylglycerol in lipid droplets in nonadipose tissue, such as skeletal muscle, is considered "normal" physiology. However, in the insulin resistant state, the level of intramyocellular lipid (IMCL) ${ }^{1}$ is increased and correlates closely and inversely with insulin sensitivity (IS) (1). Weight loss induced by caloric restriction improves IS and decreases IMCL content. These findings suggest that excessive IMCL storage is associated with "pathophysiology." On the other hand, high levels of IMCL are also observed in insulin-sensitive, endurance trained athletes (2). Exercise training, known to improve IS, increases IMCL within 2 weeks in previously untrained subjects (3). Hence, the relationship between IMCL and IS is unlikely to be causal.

In overweight subjects, caloric restriction combined with exercise training (i.e., conditions with opposite effects on IMCL) is advocated by the NIH and World Health Organization to improve health and IS. In this issue of Obesity Research, He et al. report on the combined effect of weight loss by caloric restriction and a 16-week exercise training program on IS and IMCL content (4). The investigators found that IS was improved, but IMCL content was unaffected, suggesting no involvement of IMCL in IS. Remarkably, however, IMCL was dispersed into smaller droplets after intervention and the decrement in droplet size correlated highly with improved IS.

Determination of change in size of IMCL by light microscopy is not without pitfalls. It requires very high-quality lenses and approaches the limitations in optical resolution of the most routinely used microscopes and cameras. In addition, droplet size may vary with the fixative used (5). Using external calibration standards, He et al. elegantly overcame these drawbacks, providing us with the novel and invigorating observation that size of IMCL is related to IS. How-

\footnotetext{
Departments of *Movement Sciences and †Human Biology, Maastricht University, Nutrition and Toxicology Research Institute Maastricht (NUTRIM), Maastricht, The Netherlands. Address all correspondence to Matthijs Hesselink, Department of Movement Sciences, Maastricht University, PO Box 616, NL-6200 MD Maastricht, The Netherlands. E-mail: matthijs.hesselink@bw.unimaas.nl Copyright () 2004 NAASO

${ }^{1}$ Nonstandard abbreviations: IMCL, intramyocellular lipid; IS, insulin sensitivity; DAG, diacylglycerol.
}

ever, we are left with the following question: what physiological mechanism underlies this observation?

Information on proteins controlling the storage and release of fatty acids in lipid droplets in skeletal muscle is fragmentary, but much can be learned from lipid droplets within adipocytes. In adipocytes, the phospholipid monolayer surrounding the droplet is coated with proteins controlling droplet size [e.g., members of the PAT (Perilipin A, Adipocyte differentiation-related protein, and Tail-interacting protein 47) protein family (6)]. Of the PAT proteins regulating lipid droplet size and lipase accessibility known to date, only adipocyte differentiation-related protein and Tail-interacting protein 47 are expressed in muscle and are, therefore, putative targets to manipulate lipid droplet size, thus modulating lipase accessibility.

How can droplet size affect insulin sensitivity? As a consequence of the smaller droplet size, the surface-tovolume ratio of the droplets increases. Thus, the density of PAT proteins relative to the triacylglycerol content in the droplet increases and access of cytosolic lipases involved in hydrolysis of triacylglycerol within the lipid droplet improves (7). Incomplete hydrolysis of triacylglycerol in lipid droplets, which is more likely in larger droplets due to reduced accessibility for lipases, will result in increased diacylglycerol (DAG) levels. Recent data indicate that DAG, rather than IMCL per se, impedes insulin signalling by serine phosphorylation of insulin receptor substrate 1 , thereby reducing insulin sensitivity (8).

Although reduced droplet size may improve lipase accessibility, the fatty acids released must be diverted rapidly toward oxidation to achieve complete hydrolysis of IMCL. Both the increased succinate dehydrogenase activity and mitochondrial content that $\mathrm{He}$ et al. report contribute to improved fat oxidative capacity. Hence, the improved IS reported may originate from, or require, at least two interrelated adaptive responses: 1) dispersion of IMCL in smaller droplets, permitting improved accessibility and interaction of the lipases with the triacylglycerols within the droplets and, thereby, possibly reducing DAG levels; and 2) an improved capacity to divert the fatty acids released after hydrolysis of the lipid droplets toward oxidation, preventing 
these fatty acids from lipid peroxidation, thus reducing lipotoxicity.

\section{References}

1. Szczepaniak LS, Babcock EE, Schick F, et al. Measurement of intracellular triglyceride stores by $\mathrm{H}$ spectroscopy: validation in vivo. Am J Physiol. 1999;276(5 Pt. 1):E977-89.

2. Goodpaster BH, He J, Watkins S, Kelley DE. Skeletal muscle lipid content and insulin resistance: evidence for a paradox in endurance-trained athletes. J Clin Endocrinol Metab. 2001;86:5755-61.

3. Schrauwen-Hinderling VB, Schrauwen P, Hesselink MK, et al. The increase in intramyocellular lipid content is a very early response to training. J Clin Endocrinol Metab. 2003;88: $1610-6$.

4. He J, Goodpaster BH, Kelley DE. Effects of weight loss and physical activity on muscle lipid content and droplet size. Obes Res. 2004;12:761-9.

5. DiDonato D, Brasaemle DL. Fixation methods for the study of lipid droplets by immunofluorescence microscopy. J Histochem Cytochem. 2003;51:773-80.

6. Miura S, Gan JW, Brzostowski J, et al. Functional conservation for lipid storage droplet association among Perilipin, ADRP, and TIP47 (PAT)-related proteins in mammals, Drosophila, and Dictyostelium. J Biol Chem. 2002;277:32253-7.

7. Garcia A, Subramanian V, Sekowski A, Bhattacharyya S, Love MW, Brasaemle DL. The amino and carboxyl termini of perilipin a facilitate the storage of triacylglycerols. $J$ Biol Chem. 2004;279:8409-16.

8. Itani SI, Ruderman NB, Schmieder F, Boden G. Lipidinduced insulin resistance in human muscle is associated with changes in diacylglycerol, protein kinase C, and IkappaBalpha. Diabetes. 2002;51:2005-11. 